University of Nebraska - Lincoln

DigitalCommons@University of Nebraska - Lincoln

2010

\title{
Modeling whole-tree carbon assimilation rate using observed transpiration rates and needle sugar carbon isotope ratios
}

\author{
Jia $\mathrm{Hu}$ \\ University of Colorado, jia.hu@colorado.edu \\ David J. P. Moore \\ King's College London \\ Diego Andrés Riveros-Iregui \\ University of Nebraska - Lincoln, driveros2@unl.edu \\ Sean P. Burns \\ National Center for Atmospheric Research \\ Russell K. Monson \\ University of Colorado,
}

Follow this and additional works at: https://digitalcommons.unl.edu/natrespapers

Part of the Natural Resources and Conservation Commons

Hu, Jia; Moore, David J. P.; Riveros-Iregui, Diego Andrés; Burns, Sean P.; and Monson, Russell K., "Modeling whole-tree carbon assimilation rate using observed transpiration rates and needle sugar carbon isotope ratios" (2010). Papers in Natural Resources. 208.

https://digitalcommons.unl.edu/natrespapers/208

This Article is brought to you for free and open access by the Natural Resources, School of at DigitalCommons@University of Nebraska - Lincoln. It has been accepted for inclusion in Papers in Natural Resources by an authorized administrator of DigitalCommons@University of Nebraska - Lincoln. 


\title{
Modeling whole-tree carbon assimilation rate using observed transpiration rates and needle sugar carbon isotope ratios
}

\author{
Jia Hu ${ }^{1}$, David J. P. Moore ${ }^{2}$, Diego A. Riveros-Iregui ${ }^{1}$, Sean P. Burns ${ }^{1,3}$ and Russell K. Monson ${ }^{1,4}$ \\ ${ }^{1}$ Department of Ecology and Evolutionary Biology, University of Colorado, Boulder, CO 80309, USA; ${ }^{2}$ Department of Geography, King's College \\ London, Strand, London WC2R 2LS, UK; ${ }^{3}$ National Center for Atmospheric Research (NCAR), Boulder, CO 80307, USA; ${ }^{4}$ Cooperative Institute for \\ Research in Environmental Sciences (CIRES), University of Colorado, Boulder, CO 80309, USA
}

\author{
Author for correspondence: \\ $\mathrm{Jia} \mathrm{Hu}$ \\ Tel: +1 3038186034 \\ Email: jia.hu@colorado.edu \\ Received: 9 July 2009 \\ Accepted: 21 November 2009
}

New Phytologist (2010) 185: 1000-1015 doi: 10.1111/j.1469-8137.2009.03154.x

Key words: carbon balance, conifer, mountain, photosynthesis, snow, stable isotope, sun and shade.

\section{Summary}

- Understanding controls over plant-atmosphere $\mathrm{CO}_{2}$ exchange is important for quantifying carbon budgets across a range of spatial and temporal scales. In this study, we used a simple approach to estimate whole-tree $\mathrm{CO}_{2}$ assimilation rate $\left(A_{\text {Tree }}\right)$ in a subalpine forest ecosystem.

- We analysed the carbon isotope ratio $\left(\delta^{13} \mathrm{C}\right)$ of extracted needle sugars and combined it with the daytime leaf-to-air vapor pressure deficit to estimate tree water-use efficiency (WUE). The estimated WUE was then combined with observations of tree transpiration rate $(E)$ using sap flow techniques to estimate $A_{\text {Tree }}$. Estimates of $A_{\text {Tree }}$ for the three dominant tree species in the forest were combined with species distribution and tree size to estimate and gross primary productivity (GPP) using an ecosystem process model.

- A sensitivity analysis showed that estimates of $A_{\text {Tree }}$ were more sensitive to dynamics in $E$ than $\delta^{13} \mathrm{C}$. At the ecosystem scale, the abundance of lodgepole pine trees influenced seasonal dynamics in GPP considerably more than Engelmann spruce and subalpine fir because of its greater sensitivity of $E$ to seasonal climate variation.

- The results provide the framework for a nondestructive method for estimating whole-tree carbon assimilation rate and ecosystem GPP over daily-to weekly time scales.

\section{Introduction}

Recent advances in micrometeorology have increased our knowledge of water and carbon exchange between the biosphere and atmosphere in a wide range of ecosystems (Baldocchi et al., 1988; Running et al., 1999; Canadell et al., 2000; Baldocchi, 2003). Measurements of net ecosystem exchange (NEE) of $\mathrm{CO}_{2}$ have been useful in constraining global carbon budgets and have allowed researchers to measure NEE over many years and in various climate regimes (Baldocchi \& Wilson, 2001). While NEE can be used to determine if an ecosystem is a net carbon sink or source, NEE measurements represent the balance between two gross fluxes - carbon uptake through net photosynthesis (gross primary productivity, GPP) and carbon release through heterotrophic and autotrophic respiration $\left(R_{\mathrm{E}}\right)$.
The magnitudes of these components cannot be resolved with NEE measurements alone.

There are many methods, at a range of scales, designed for quantifying GPP. Past studies have relied on vegetation models that combine leaf-level measurements with satellite imaging to estimate GPP (Lloyd \& Farquhar, 1994; Running et al., 1999). Many of these studies depend on the normalized difference vegetation index (NDVI), which is derived from satellite images and used to estimate GPP for large areas of the globe (Myneni et al., 1997; Schimel et al., 2002; Angert et al., 2005; Goetz et al., 2005). In a second approach, observations from flux towers can be assimilated into ecosystem process models, and the model can be used to partition NEE into its component processes, GPP and $R_{\mathrm{E}}$ (Sacks et al., 2006, 2007; Moore et al., 2008); models can also be combined with observations of tree- and needle- 
scale processes to estimate canopy-scale fluxes of $\mathrm{CO}_{2}$ and $\mathrm{H}_{2} \mathrm{O}$ (Schäfer et al., 2003, 2009; Kim et al., 2008). At the scale of a single leaf, the processes that determine GPP have also been well resolved. Leaf $\mathrm{CO}_{2}$ exchanges are typically measured using gas exchange systems (Field et al., 1982) and analysed by biochemically based flux models (Farquhar et al., 1980). Between the scales of the leaf and ecosystem, however, lies the whole plant and relatively fewer studies have been devoted to observations and models at the wholeplant scale. Rates of $\mathrm{CO}_{2}$ assimilation at the whole-plant scale have been made with (1) plant chambers in the case of small plants (Denmead et al., 1993) but this approach is not feasible for large trees, and (2) using biometric techniques (McGee et al., 1999; Barford et al., 2001; Clark et al., 2001), which is limited to discerning tree NPP across timescales of weeks to months.

In this study, we developed an approach to estimate net $\mathrm{CO}_{2}$ assimilation rate at the whole-tree scale based on the theory of photosynthetic water-use efficiency (WUE). Photosynthetic WUE is the molar ratio of net $\mathrm{CO}_{2}$ assimilation rate $(A)$ to transpiration rate $(E)$ (WUE $=A: E$ ) (Farquhar et al., 1989). We used sap flow sensors to measure $E$ at the whole-tree scale and analysed the carbon isotope ratio $\left(\delta^{13} \mathrm{C}\right)$ of recently produced needle sugars to estimate WUE. These observations allowed us to estimate $\mathrm{CO}_{2}$ uptake rate at the tree scale. We used our calculations of whole-tree carbon assimilation, combined with forest stand information, to estimate ecosystem GPP and compared this type of estimate with that obtained from an ecosystem process model conditioned on $10 \mathrm{yr}$ of eddy flux observations. Finally, we conducted a sensitivity analysis to determine the most likely sources of error in our procedure for estimating tree photosynthesis.

\section{Materials and Methods}

\section{Study site and meteorology}

Our studies were conducted during the summers of 2006 and 2007 at the Niwot Ridge AmeriFlux site, located in a subalpine forest (elevation $3050 \mathrm{~m}$ ) in the Colorado Rocky Mountains (CO, USA). The forest is $c .100 \mathrm{yr}$ old and the three dominant tree species are Pinus contorta Douglas ex Louden (lodgepole pine), Abies lasiocarpa (Hook.) Nutt (subalpine fir) and Picea engelmanii Parry ex. Engelm. (Engelmann spruce). Mean annual temperature is $1.5^{\circ} \mathrm{C}$ and average precipitation is $800 \mathrm{~mm}$, of which c. $60 \%$ is in the form of winter snow (for a more detailed description of the site see Monson et al., 2002, 2005). Stand characteristics were measured in a previous study (Monson et al., 2009) and some of the characteristics are reported in Table 1.

We obtained snow water equivalent (SWE) values for the Niwot Ridge Long Term Ecological Research (LTER) C1 site from the US Department of Agriculture SNOTEL
Table 1 Stand characteristics of the forest east and west of the Niwot Ridge AmeriFlux tower

\begin{tabular}{lll}
\hline & East & West \\
\hline $\begin{array}{l}\text { Tree distribution (trees } \mathrm{m}^{-2} \text { ) } \\
\quad \text { Abies lasiocarpa (subalpine fir) }\end{array}$ & $0.10 \pm 0.006$ & $0.16 \pm 0.01$ \\
$\quad \begin{array}{l}\text { Picea engelmannii } \\
\quad \text { Engelmann spruce) }\end{array}$ & $0.07 \pm 0.003$ & $0.10 \pm 0.003$ \\
$\quad \begin{array}{l}\text { Pinus contorta } \\
\quad \text { lodgepole pine) }\end{array}$ & $0.27 \pm 0.008$ & $0.09 \pm 0.003$ \\
Total & $0.44 \pm 0.017$ & $0.35 \pm 0.016$ \\
Total aboveground & 22.41 & 24.17 \\
biomass $\left(\mathrm{kg} \mathrm{m}^{-2}\right)$ & 3.54 & 4.02 \\
Leaf biomass $\left(\mathrm{kg} \mathrm{m}^{-2}\right)$ & $3.8 \pm 0.3$ & $4.2 \pm 0.4$ \\
LAl (1999) $\left(\mathrm{m}^{2} \mathrm{~m}^{-2}\right)$ & $3.1 \pm 0.3$ & $3.8 \pm 0.3$ \\
\hline LAl (2006) $\left(\mathrm{m}^{2} \mathrm{~m}^{-2}\right)$ & & \\
\hline
\end{tabular}

Error estimates equal $\pm 1 \mathrm{SE}$. The two hemispherical needle area index ( $\mathrm{LAl}$ ) estimates refer to the two different campaigns used to construct biometric estimates of LAI distribution (adapted from Monson et al., 2009).

database (http://www.co.nrcs.usda.gov/snow/snow/) for 2006 and 2007. We have reported SWE as the running accumulation of daily sums. Values were obtained for air temperature and atmospheric saturation vapor pressure deficit (VPD) from 30-min averaged measurements at two heights $(2 \mathrm{~m}$ and $21.5 \mathrm{~m})$, and evapotranspiration from $21.5 \mathrm{~m}$, using the Niwot Ridge AmeriFlux database (http:// urquell.colorado.edu/data_ameriflux/). Precipitation was measured using a heated tipping bucket gauge (Met One, Inc., Grants Pass, OR, USA) with a data logger (model 23X; Campbell Scientific, Logan UT, USA). We measured volumetric soil moisture $(\theta)$ and its seasonal dynamics at two depths $(5 \mathrm{~cm}$ and $15 \mathrm{~cm})$, using time-domain reflectometry probes (models CS615 and CS616; Campbell Scientific).

\section{Tree transpiration rate measurements}

We measured transpiration rate in all three dominant tree species using the heat ratio sap flow method (Marshall, 1958; Burgess et al., 2001). Each sensor includes a heater (which emits a heat pulse) located between two thermocouples (which detect dispersion of the heat pulse). Each thermocouple had two junctions separated by $1.7 \mathrm{~cm}$ along the axis of insertion; this allowed for measurements at two depths $(1.8 \mathrm{~cm}$ and $3.5 \mathrm{~cm})$. Data collection and control over heat pulsing was accomplished using data loggers with multiplexers (models CR10X and AM4/16, respectively; Campbell Scientific). Heat pulse velocity $\left(V_{\mathrm{h}}\right)$ was measured and calculated every 30 min as:

$V_{\mathrm{h}}=k / x \times \log _{\mathrm{e}}\left(v_{1} / v_{2}\right) \times 1800$

Eqn 1

( $k$ is the thermal diffusivity of wood $\left(0.25 \mathrm{~cm}^{2} \mathrm{~s}^{-1}\right)$; $x$ is the vertical distance between the heater and thermocouples 
$(0.6 \mathrm{~cm}) ; v_{1}$ is the change in temperature from the thermocouples downstream; and $v_{2}$ is the change in temperature from the thermocouple upstream). From $V_{h}$, sap flux velocity $\left(V_{s}\right)$ was calculated as:

$V_{\mathrm{s}}=\left[V_{\mathrm{h}} \rho_{\mathrm{b}}\left(c_{\mathrm{w}}+m_{\mathrm{c}} c_{\mathrm{s}}\right)\right] / \rho_{\mathrm{s}} \times c_{\mathrm{s}}$,

Eqn 2

( $\rho_{\mathrm{b}}$ is the volumetric density of wood $\left(\mathrm{kg} \mathrm{cm}^{-3}\right) ; c_{\mathrm{w}}$ is the specific heat capacity of wood $\left(1200 \mathrm{~J} \mathrm{~kg}^{-1}{ }^{\circ} \mathrm{C}^{-1}\right) ; c_{\mathrm{s}}$ is the specific heat capacity of water $\left(4182 \mathrm{~J} \mathrm{~kg}^{-1}{ }^{\circ} \mathrm{C}^{-1}\right) ; m_{\mathrm{c}}$ is the volumetric water content of sapwood $\left(\mathrm{cm}^{3} \mathrm{~cm}^{-3}\right)$; and $\rho_{\mathrm{s}}$ is the density of water $\left.\left(0.001 \mathrm{~kg} \mathrm{~cm}^{-3}\right)\right)$. Density was taken as wood DW per fresh volume after coring trees, measuring the volume of each core using a caliper (resolution: $0.01 \mathrm{~mm}$; Fisher Scientific, Pittsburg, PA, USA) and then drying the sample at $100^{\circ} \mathrm{C}$. Water content was calculated as: (wet wood weight - dry wood weight)/dry wood weight.

Daily transpiration rate $(E)$ per tree was calculated as the product of the sap wood area $\left(\mathrm{cm}^{2}\right)$ at breast height and $V_{s}$. Because the thermocouples were inserted to two depths, we were able to measure sap flux for at least two radially arranged concentric zones. The first zone was taken as the area beginning from a distance halfway between the two thermocouple to the bark $(2.65 \mathrm{~cm}$ diameter ring). The area of the second zone was calculated as a concentric ring $2.65 \mathrm{~cm}$ in diameter, inside the first ring. Depending on the diameter of the tree, and the species, additional concentric zones were also calculated, with each zone getting smaller (progressing from outside to inside), but with each zone no more than $2.65 \mathrm{~cm}$ in diameter. For trees with diameters that exceeded the depth of the thermocouples, we used a well-established relationship between sapwood depth and sap flux (Mark \& Crews, 1973) to estimate sap flux beyond the extent of the thermocouples (Pataki et al., 2000). Total transpiration rate per tree $\left(E_{\mathrm{T}}\right)$ was calculated as the sum of sap fluxes for all concentric zones. We also calculated transpiration rate per unit sapwood area $\left(E_{\mathrm{SA}}\right)$ and per unit leaf area $\left(E_{\mathrm{LA}}\right)$ to account for differences in sapwood depth and needle area. In the first case, we determined sapwood depth using destructive harvesting techniques to visually determine the sapwood to heartwood ratio. In the latter case we used a relationship between species diameter at breast height $(\mathrm{DBH})$ and tree hemispherical needle area: hemispherical needle area $\left(\mathrm{m}^{2}\right)=3.9$ bole diameter $(\mathrm{cm})-16.5$; $R^{2}=0.83, P<0.01$, which described the scaling for all three of the dominant tree species at the study site (Monson et al., 2009).

Sap flux sensors were installed on 5 May 2006 and 10 May 2007 into eight fir trees, nine pine trees, and eight spruce trees. The trees were approximately evenly distributed between two plots $(10 \times 70 \mathrm{~m})$ located east and west of the flux tower. We chose trees with a relatively even concentric distribution of branches and needle area and from a range of diameters at breast height. The fir $\mathrm{DBH}$ ranged from 0.11 to $0.26 \mathrm{~m}$, with a mean of $0.15 \mathrm{~m}$, pine $\mathrm{DBH}$ ranged from 0.09 to $0.27 \mathrm{~m}$, with a mean of $0.19 \mathrm{~m}$, and spruce DBH ranged from 0.10 to $0.32 \mathrm{~m}$, with a mean of $0.18 \mathrm{~m}$. These tree sizes are typical of the dominant, mature trees within the forest. In a preliminary study we placed sap flux sensors at all four cardinal directions of three trees of each species with $\mathrm{DBH}$ in the same ranges as those described above, and determined that the error between estimates of any one sensor and all of the other sensors was $14-17 \%$ (data not shown). Analysis of variance of these flux measurements showed no significant effect of cardinal direction on observed flux. Thus, we used only one sap flux sensor per tree, with replicate trees.

In order to scale tree sap flux to the ecosystem, we used the methods described in Moore et al. (2008) and the forest stand data described in Monson et al. (2009). Briefly, we calculated ecosystem $E$, in units of $\mathrm{g}_{2} \mathrm{O} \mathrm{m}^{-2}$ ground area, by multiplying $E_{\mathrm{SA}}$ by the proportion of sapwood area for each of the three species within a $1-\mathrm{m}^{2}$ ground area, and then summing the $E$-values for all three species (Table 1).

\section{Needle sugar carbon isotope measurements}

Needle sugars were collected every $14 \mathrm{~d}$ during the growing season. In 2006, needles were collected from 2 June to 31 August, and in 2007 from 11 May to 28 August. In 2006, only sun needles were collected, while in 2007 both sun and shade needles were collected. Sun needles were collected from western- and eastern-exposed faces of the upper third of the tree crown, and shade needles were collected from the lower third of the crown. New needles did not bud until mid-June and were not fully expanded until mid-July. We extracted sugars from needles from the previous year's growth up to mid-July, at which time we switched to needles from the current year; our aim was to sample the most recently produced, fully expanded needles in all cases. We analysed current-year needles and previous-year needles collected during late July 2006 and found no significant differences $(P>0.05)$ in the ${ }^{13} \mathrm{C}:{ }^{12} \mathrm{C}$ ratio of sugars extracted from each. It is unknown whether needles older than $1 \mathrm{yr}$ operated at different photosynthetic WUE than those of the current year, and therefore we assumed that needles of different ages had similar photosynthetic WUEs. We have analysed needles from different positions along the length of branches of each species with respect to tissue ${ }^{13} \mathrm{C}:{ }^{12} \mathrm{C}$ ratios, and found no significant difference (data not shown). While there is a possibility that the lack of difference in ${ }^{13} \mathrm{C}:{ }^{12} \mathrm{C}$ ratio may reflect homogenization through intrabranch translocation of sugars across the lifespan of the needles, we assume that if large differences in photosynthetic WUE exist among the needles, we should detect some evidence of this in the isotope ratios of collected tissue samples; thus, we have used the lack of difference as reason to pro- 
ceed with our assumption of no significant effect of needle age on WUE. During collection, needles were removed and quickly frozen in liquid nitrogen. Soluble sugar extracts were obtained following the protocol from Gessler et al. (2004) (see the Supporting Information, Methods S1). Soluble sugars were analysed for ${ }^{13} \mathrm{C}:{ }^{12} \mathrm{C}$ ratios at the Center for Stable Isotope Biogeochemistry at the University of California, Berkeley (CA, USA). The ${ }^{13} \mathrm{C}:{ }^{12} \mathrm{C}$ ratio is expressed using $\delta$ notation $\left(\delta^{13} \mathrm{C}\right)$ with units of parts per thousand $(\%)$.

\section{Calculating plant WUE}

We used $\delta^{13} \mathrm{C}$ from needle sugars to calculate $C_{\mathrm{i}}: C_{\mathrm{a}}$ using the linear model from Farquhar et al. (1982), where $C_{\mathrm{i}}$ is the $\mathrm{CO}_{2}$ concentration in the intercellular air spaces of the needle and $C_{\mathrm{a}}$ is the above-canopy atmospheric $\mathrm{CO}_{2}$ concentration. The isotope discrimination factor, $\Delta$, was calculated as:

$\Delta=\left({ }^{13} C_{\mathrm{a}}-{ }^{13} \mathrm{C}_{\mathrm{p}}\right) /\left(1+{ }^{13} \mathrm{C}_{\mathrm{p}}\right)$,

Eqn 3

$\left({ }^{13} \mathrm{C}_{\mathrm{a}}\right.$ is the isotope value of the above-canopy atmosphere $\left(-8.5 \%\right.$ at this site; Bowling et al., 2005); ${ }^{13} \mathrm{C}_{\mathrm{p}}$ is the ${ }^{13} \mathrm{C}:{ }^{12} \mathrm{C}$ isotope ratio of the needle sugars). Then $C_{\mathrm{i}}: C_{\mathrm{a}}$ was calculated from:

$C_{\mathrm{i}}: C_{\mathrm{a}}=(\Delta-a) /(b-a)$

Eqn 4

( $a$ is the fractionation caused by the diffusion of $\mathrm{CO}_{2}$ in air $(4 \%) ; b$ is the fractionation resulting from the active site of the enzyme, Rubisco $(27 \%)$ ). Instantaneous WUE is calculated as:

$\mathrm{WUE}=A: E=\left(C_{\mathrm{a}}-\mathrm{C}_{\mathrm{i}}\right) / 1.6 v$,

Eqn 5

( $A$ is molar rate of carbon assimilation; $E$ is the molar rate of transpiration; 1.6 is the ratio of the diffusivities of water vapor and $\mathrm{CO}_{2}$ in air; $v$ is the water vapor pressure difference between the intercellular spaces of the leaf and the well-mixed atmosphere outside the leaf $(\mathrm{kPa}))$. We calculated $v$ as:

$v=p_{\mathrm{lf}}-p_{\mathrm{atm}}$

Eqn 6

( $p_{\mathrm{If}}$ and $p_{\mathrm{atm}}$ are the vapor pressures inside the leaf and atmosphere, respectively). Vapor pressure $p_{\text {If }}$ was calculated as:

$p_{\text {lf }}=\exp \left[52.57633-(6790.49 / T)-5.02808 \log _{\mathrm{e}} T\right]$

where $T$ is absolute temperature (Campbell, 1977), and was taken as the air temperature measured at $21.5 \mathrm{~m}$ height for sun needles and $2 \mathrm{~m}$ height for shade needles. Thus, we have made the implicit assumption that needle temperature equaled air temperature at both heights. This assumption was made because previous studies have found that when coniferous forests are well coupled with the atmosphere, there is only a small difference between air and needle temperatures measured above and within the canopy (Kaufmann, 1985; Clark et al., 2009; Schäfer et al., 2009). We compared air temperature measured above the canopy $(21.5 \mathrm{~m})$ with air temperature measured within the canopy $(8 \mathrm{~m})$ through the growing season and found the air temperature to differ, on average, by only $1.2^{\circ} \mathrm{C}$.

Atmospheric vapor pressure $\left(p_{\text {atm }}\right)$ was determined from air temperature and relative humidity measured at $21.5 \mathrm{~m}$ for sun needles and $2 \mathrm{~m}$ height for shade needles. We then averaged $v$ for $3 \mathrm{~d}$ before the collection of needle sugars, and between $09: 00 \mathrm{~h}$ to $18: 00 \mathrm{~h}$. We chose $3 \mathrm{~d}$ as our averaging period after reasoning that the sugar turnover time in the needles is likely to be less than this, even with conservative assumptions. For example, Sevanto et al. (2003) found that sugars were transported out of needles on the scale of hours during periods of active photosynthesis. We have allowed for some diurnal storage of sugars in needles, and thus estimated that sugars should, at most, reflect up to $3 \mathrm{~d}$ of past weather influences.

Recent studies have suggested that the 'linear' model for calculating $\Delta$ (Eqn 4) overestimates intrinsic WUE (iWUE), relative to a more detailed consideration (Seibt et al., 2008). An alternative model that has been used to describe iWUE is the 'classic equation', which takes into consideration parameters such as mesophyll conductance and fractionation associated with photorespiration (Wingate et al., 2007; Seibt et al., 2008). We also tested the sensitivity of WUE using $C_{\mathrm{i}}: C_{\mathrm{a}}$ derived from both the linear and classical equations but did not find differences in WUE calculated using the two different equations (see Methods S2).

\section{Modeling whole-tree carbon assimilation $\left(A_{\text {Tree }}\right)$}

We modeled whole-tree carbon assimilation rate $\left(A_{\text {Tree }}\right)$ using the relationship WUE $=A: E$, and used averaged $\delta^{13} \mathrm{C}$ of needle sugars to estimate whole-tree WUE and sap flux to calculate $E_{\mathrm{T}}$. We then multiplied WUE by $E$ to calculate $A$, which we expressed using two different bases: per tree and per unit ground area. In 2006, we only collected sun needles; however, in 2007, we collected both shade and sun needles and could therefore calculate whole-tree WUE taking into account differences in WUE between sun and shade canopy environment. We chose three hypothetical scenarios for sun and shade needle proportions within the tree crown: (1) $50 \%$ sun and $50 \%$ shade; (2) $25 \%$ sun and $75 \%$ shade; (3) $15 \%$ sun and $85 \%$ shade. We then multiplied the per cent sun vs shade needle fractions by the 
respective $\delta^{13} \mathrm{C}$ value for individual sun vs shade needles to calculate the average $\delta^{13} \mathrm{C}$ value for the entire tree.

\section{Scaling $A_{\text {Tree }}$ to GPP}

In order to scale $A_{\text {Tree }}$ to ecosystem GPP, we used leaf area index (LAI) data and the spatial distribution of trees described in Monson et al. (2009). We then used the following equation to calculate GPP $\left(\mathrm{g} \mathrm{C} \mathrm{m}^{-2} \mathrm{~d}^{-1}\right)$ for the forest flux fetches east and west of the tower:

$\mathrm{GPP}=\sum_{\mathrm{p}, \mathrm{s}, \mathrm{f}} \frac{A_{\text {Tree }} f \text { LAI }}{\text { HSA }}$

( $\mathrm{p}, \mathrm{s}$ and $\mathrm{f}$ are pine, spruce and fir, respectively as summed quantities; $A_{\text {Tree }}$ is the modeled $\mathrm{CO}_{2}$ assimilation rate, which was determined separately for trees east and west of the tower; $f$ is the fraction of trees belonging to each species per $\mathrm{m}^{2}$ ground area; LAI is hemispherical needle area index for the forest; and HSA is the average hemispherical needle area per tree for each species). Equation 8 scales $A_{\text {Tree }}$ to a unit ground area (congruent to GPP) according to the fractional representation of needle area for each species, but inherent in Eqn 8 is the assumption that $A_{\text {Tree }}$ expressed per unit HSA is the same irrespective of tree size. Ecosystem GPP was calculated by weighting the GPP from the eastern vs western forest fetches by the direction of wind.

\section{Simplified photosynthesis and evapotranspiration model}

The simplified photosynthesis and evapotranspiration (SIPNET) model that we used is based on the photosynthesisevapotranspiration (PnET) family of models (Aber \& Federer, 1992; Aber et al., 1995, 1996). The SIPNET model contains two vegetation carbon pools and an aggregated soil carbon pool, and simulates the carbon dynamics between these pools and the atmosphere. The vegetation pool is split into leaves and wood, where 'wood' refers to the combined pool of boles, branches and roots. The model performs two time-steps per day: day and night.

Both net ecosystem productivity (NEP) and evapotranspiration (ET) observations from the Niwot Ridge AmeriFlux tower were used to parameterize the SIPNET model. The scheme used to assess the maximum likelihood outcomes of the model are discussed in Braswell et al. (2005), Sacks et al. (2006) and Moore et al. (2008). In this data assimilation and analysis, GPP was constrained by the flux record from 1999 through 2008. Once the model parameters were optimized using the $10-y r$ data set, we ran the model forward to estimate GPP averaged over $3 \mathrm{~d}$ before each of our 2006 and 2007 isotope sampling campaigns, using separate climate drivers for each day.

\section{Statistics and sensitivity analysis}

In order to test for differences in $\delta^{13} \mathrm{C}$ of needle sugars and WUE (1) among species, (2) between sun and shade needles and (3) throughout the growing season, we used an ANOva, repeated measures approach, with each tree sampled for $\delta^{13} \mathrm{C}$ as a repeated measure (SAS 9.2; The SAS Institute, Cary, NC, USA). We took a regular ANOvA approach to test for differences in $\mathrm{E}$ and $A_{\text {Tree }}$ : (1) among species, (2) between years and (3) throughout the growing season. We used regression analysis (SAS) to test for relationships between $E_{S A}$ and the following environmental variables: soil moisture $(\theta)$, air temperature and VPD. In 2006 the dates used for statistical analysis of daily $E$ were from May 19 and August 31, and in 2007 the dates ranged from May 15 to August 28.

In order to quantify error propagation when modeling $A_{\text {Tree }}$ and GPP based on measurements of $\delta^{13} \mathrm{C}$ and E, we applied a Monte Carlo method (Hollinger \& Richardson, 2005; Ricciuto et al., 2008) (Matlab R2008B, The MatWorks). This approach accounted for all known parameter uncertainties in calculating $A_{\text {Tree}}$, including $\delta^{13} \mathrm{C}$ of needle sugars (differences influenced by needle position and age) and $E$ (differences influenced by radial patterns, azimuth direction, and tree size); this approach also accounted for all known parameter uncertainties in calculating GPP, including $A_{\text {Tree }}$, relationship between tree size and needle area, per cent species composition, LAI and variation in VPD during the 3-d integration. For each selected day (6 d in 2006 and $9 \mathrm{~d}$ in 2007), we modeled GPP in an iterative manner (10 000 times) and randomly sampled from a range of uniformly distributed $\delta^{13} \mathrm{C}$ and $E$ values to calculate $A_{\text {Tree }}$. Thus, we were able to estimate $A_{\text {Tree }}$ and GPP without the constraint of limited sampling frequency and could determine the sensitivity of the estimated $A_{\text {Tree }}$ and GPP to both $E$ and $\delta^{13} \mathrm{C}$. The range of the values used for constructing the pool of simulations was determined a priori (Table 2). The results of the calculations of GPP are reported as the median of simulations for each day and a $99 \%$ confidence interval in Fig. 6. Because $A_{\text {Tree }}$ and GPP were modeled

Table 2 The range of $\delta^{13} \mathrm{C}$ and transpiration per tree $\left(E_{\mathrm{T}}\right)$ measured in the field and then used to generate the $99 \%$ confidence intervals using the Monte Carlo approach

\begin{tabular}{llll}
\hline & & \multicolumn{2}{l}{ Range of observations } \\
\cline { 3 - 4 } Year & Species & $\delta^{13} \mathrm{C}(\%)$ & $\begin{array}{l}E_{\mathrm{T}}\left(\mathrm{g} \mathrm{H}_{2} \mathrm{O}\right. \\
\left.\text { per tree } \mathrm{d}^{-1}\right)\end{array}$ \\
\hline \multirow{2}{*}{2006} & Subalpine fir & -29.07 to -27.95 & 176.59 to 943.17 \\
& Lodgepole pine & -27.69 to -26.69 & 1846.4 to 6533.30 \\
& Engelmann spruce & -27.47 to -26.90 & 2058.70 to 4426.30 \\
2007 & Subalpine fir & -29.04 to -27.01 & 242.46 to 1126.70 \\
& Lodgepole pine & -27.87 to -25.93 & 213.90 to 6846.40 \\
& Engelmann spruce & -27.84 to -26.39 & 2290.60 to 6697.00 \\
\hline
\end{tabular}


New

using both measurements of $\delta^{13} \mathrm{C}$ and $\mathrm{E}$, we used random values drawn from the same pool of $A_{\text {Tree }}$ and GPP values used in the Monte Carlo analysis, and examined the sensitivity of $A_{\text {Tree }}$ and GPP to $\delta^{13} \mathrm{C}$ and $E$ as independent variables. We plotted the linear regression relationships plus $95 \%$ confidence intervals from this analysis for the data reported in Fig. 9.

\section{Results}

\section{Meteorological measurements}

The growing season of 2006 was drier than 2007. The cumulative SWE of the snowpack in 2006 was $43.9 \mathrm{~cm}$ (Fig. 1a), c. 10\% below the previous 9 -yr mean $(49.07 \mathrm{~cm})$, while the SWE in 2007 was $59.7 \mathrm{~cm}$ (Fig. 1b), c. 22\% above the previous 9-yr mean (1999-2007). In 2006, sum- mer precipitation was $24.03 \mathrm{~cm}, 22 \%$ below the previous 9yr mean $(30.8 \mathrm{~cm})$, while in 2007 , summer precipitation was $31.2 \mathrm{~cm}$, which was close to the mean (Fig. 1b,c).

\section{Transpiration measurements}

We calculated transpiration rates expressed as both per tree $\left(E_{\mathrm{T}}\right)$ and per unit sapwood area $\left(E_{\mathrm{SA}}\right)$ and both showed the same seasonal and species patterns (Fig. 2). During the 2006 growing season, the seasonal mean values for $E_{\mathrm{SA}}$ were significantly different among all three species $(P<0.05)$, with pine trees generally exhibiting the highest $E_{\mathrm{SA}}$ (seasonal mean $=18.94 \mathrm{~g} \mathrm{H}_{2} \mathrm{O} \mathrm{cm} \mathrm{cm}^{-2}$ ), followed by spruce (seasonal mean $=13.71 \mathrm{~g} \mathrm{H}_{2} \mathrm{O} \mathrm{cm} \mathrm{cm}^{-2} \mathrm{~d}^{-1}$ ) and then fir (seasonal mean $\left.=5.39 \mathrm{~g} \mathrm{H}_{2} \mathrm{O} \mathrm{cm}^{-2} \mathrm{~d}^{-1}\right)$. In 2007, $E_{\mathrm{SA}}$ was higher than in 2006 for all three species $(P<0.05$ for all three species). During the 2007 growing season, once again,
Fig. 1 Daily values of: $(a, b)$ snow water equivalent (SWE); (c,d) precipitation; $(e, f)$ soil moisture $(\theta)$ measured at $5 \mathrm{~cm}$ (black line) and $15 \mathrm{~cm}$ depth (gray line); (g,h) vapor pressure deficit (VPD) for 2006 and 2007.

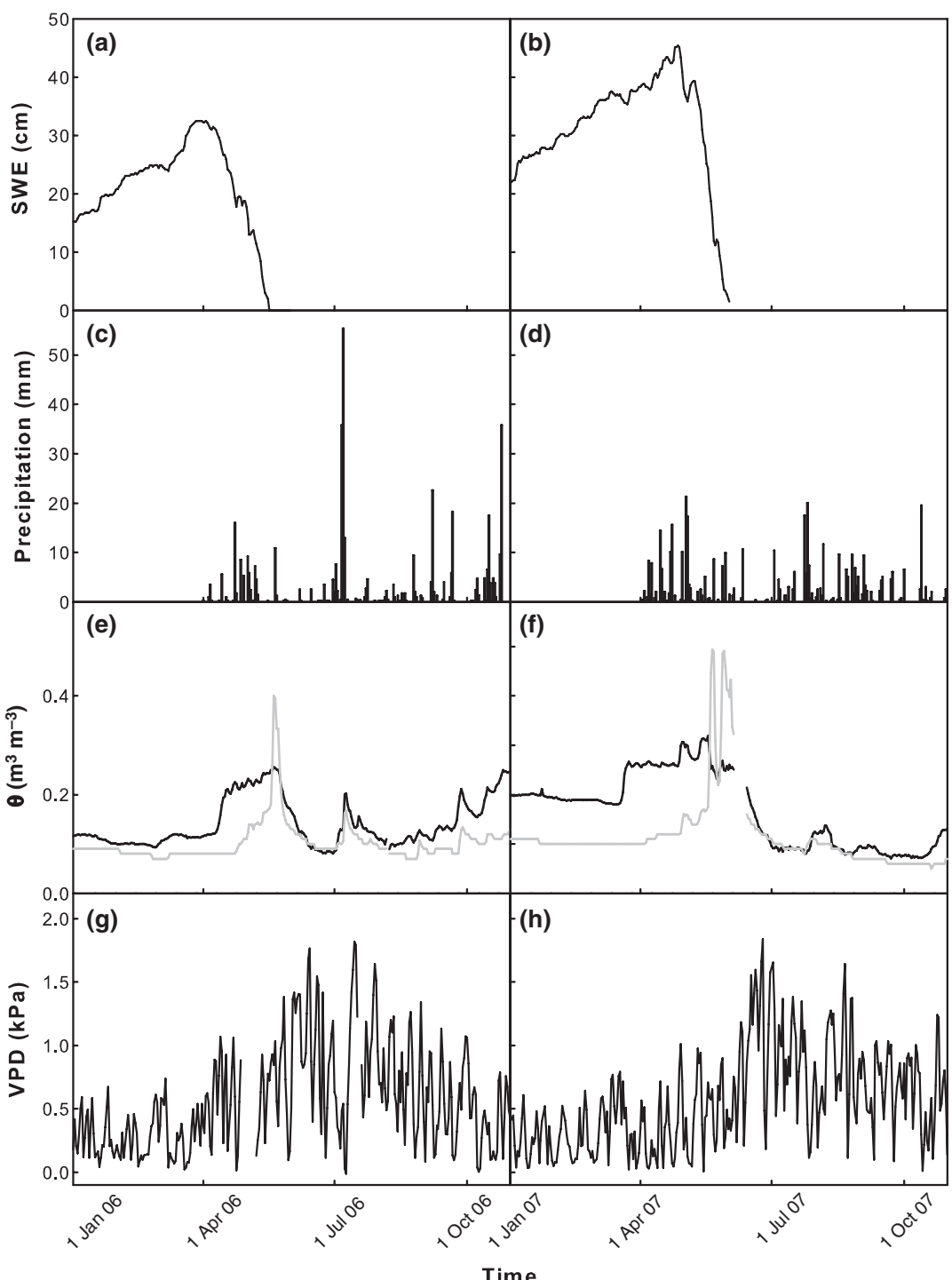


daily mean $E_{\mathrm{SA}}$ was not significantly different between pine and spruce, but it was different between fir and either pine or spruce $(P<0.001)$, with pine once again exhibiting the highest $E_{\mathrm{SA}}$ (seasonal mean $=28.15 \mathrm{~g} \mathrm{H}_{2} \mathrm{O} \mathrm{cm}^{-2} \mathrm{~d}^{-1}$ ), followed by spruce (seasonal mean $=21.67 \mathrm{~g} \mathrm{H}_{2} \mathrm{O} \mathrm{cm}^{-2} \mathrm{~d}^{-1}$ ) and then fir (seasonal mean $=5.8 \mathrm{~g} \mathrm{H}_{2} \mathrm{O} \mathrm{cm}^{-2} \mathrm{~d}^{-1}$ ). We also observed a significant linear relationship between $\mathrm{E}_{\mathrm{SA}}$ and air temperature, and a nonlinear exponential rise to maximum relationship for $E_{\mathrm{SA}}$ and VPD for both 2006 and 2007 (Table 3; Fig. 3). We observed a significant linear relationship between $E_{\mathrm{SA}}$ and $\theta$ in 2006, but not in 2007 .

Our comparison between ecosystem transpiration $(E)$ and ecosystem evapotranspiration demonstrated that in both years, $E$ was consistently lower than evapotranspiration (Fig. 4). Furthermore, the seasonal patterns of $E$ followed the patterns of evapotranspiration. In 2007, we found that a greater proportion of total evapotranspiration was caused by $E$ than in 2006 .

\section{Needle sugar carbon isotope measurements and plant WUE}

We observed differences in the $\delta^{13} \mathrm{C}$ values of needle sugars among the three tree species $(P<0.0001$ for both years), as well as an effect of date $(P<0.0001$ for both years). Fir

Table 3 Regression coefficients, statistical significance and regression relationships between daily transpiration per unit sapwood area $\left(E_{S A}\right)$ vs air temperature, vapor pressure deficit (VPD) and soil moisture $(\theta)$ at $15 \mathrm{~cm}$ for 2006 and 2007

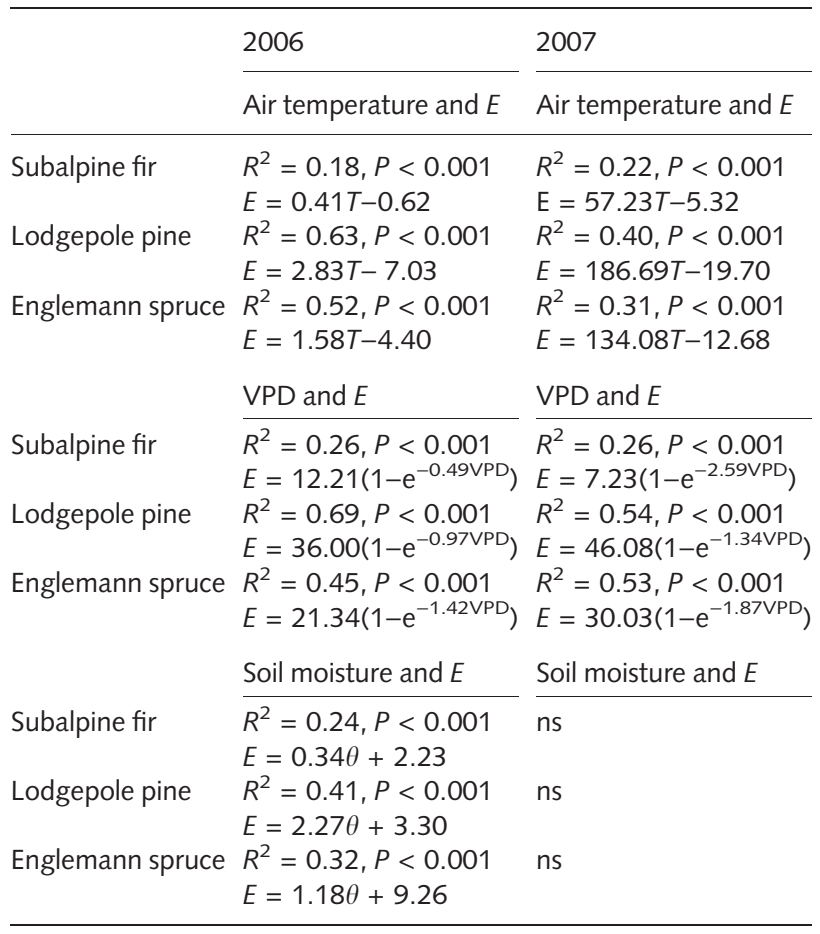

ns, not significant. needles exhibited the most negative $\delta^{13} \mathrm{C}$, while pine and spruce needles exhibited a similar range of $\delta^{13} \mathrm{C}$ values (Fig. 5). The needle sugars extracted during the early part of the growing season were also more enriched in ${ }^{13} \mathrm{C}$ compared with those extracted closer to the end of the growing season. In 2007, we also found a significant difference between sun and shade needle $\delta^{13} \mathrm{C}$ values $(P<0.0001)$ (shade data not shown). Calculated $C_{\mathrm{i}}: C_{\mathrm{a}}$ values also showed a seasonal pattern that had an inverse relationship with $\delta^{13} \mathrm{C}$ values (Fig. 5). These $C_{\mathrm{i}}: C_{\mathrm{a}}$ values were consistent with branch-scale gas exchange measurements reported in Huxman et al. (2003).

In 2006, we calculated the highest tree WUE values during the first collection date ( 1 June), with values of $13.02 \pm 1.01, \quad 15.51 \pm 0.444$ and $14.74 \pm 0.22 \mathrm{mmol}$ $\mathrm{mol}^{-1}$ for fir, pine and spruce, respectively (Fig. 6). The WUE values then decreased for the remainder of the growing season. In 2007, however, there were two observation dates with high WUE: 24 May and 31 July (Fig. 6). In both 2006 and 2007, all three species had significantly different WUE $(P<0.0001)$, with fir being significantly different from pine and spruce $(P<0.001)$, but pine and spruce were not different. Furthermore, in 2007, we did not see a significant difference in tree WUE using the different fractional sun and shade needle scenarios (Fig. 6).

\section{Whole-tree carbon assimilation}

In 2006, the highest $A_{\text {Tree }}$ values occurred on 1 June, with values of $7.88 \pm 1.68 \mathrm{~g} \mathrm{C}$ per tree $\mathrm{d}^{-1}, 63.12 \pm 20.98 \mathrm{~g} \mathrm{C}$

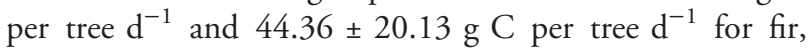
pine and spruce, respectively (Fig. 7). The $A_{\text {Tree }}$ value then decreased for the remainder of the growing season. In 2007, $A_{\text {Tree }}$ oscillated more from one collection date to the next. There were three observation dates when $A_{\text {Tree }}$ values were significantly higher than on other dates, but not different from one another: 6 June, 6 July and 31 July (Fig. 7). When considering observations across the entire season, we found significant differences in $A_{\text {Tree }}$ among the three species $(P<0.0001)$; values for fir were different from those for pine $(P<0.0005)$ and spruce $(P<0.0001)$, but values for pine and spruce were not different from each other. Once again, we did not find significant differences in $A_{\text {Tree }}$ that were dependent on the different sun and shade needle scenarios.

\section{Modeled gross primary productivity}

The GPP values estimated from $E$ and $\delta^{13} \mathrm{C}$ were generally lower than those obtained from the SIPNET modeling (Fig. 8). In 2006, SIPNET modeled GPP ranged from 1.40 to $2.63 \mathrm{~g} \mathrm{C} \mathrm{m}^{-2} \mathrm{~d}^{-1}$, with an average value of $2.25 \mathrm{~g} \mathrm{C}$ $\mathrm{m}^{-2} \mathrm{~d}^{-1}$ for the entire growing season; the highest GPP occurred on 22 July. The estimated values of GPP using 
New

Phytologist

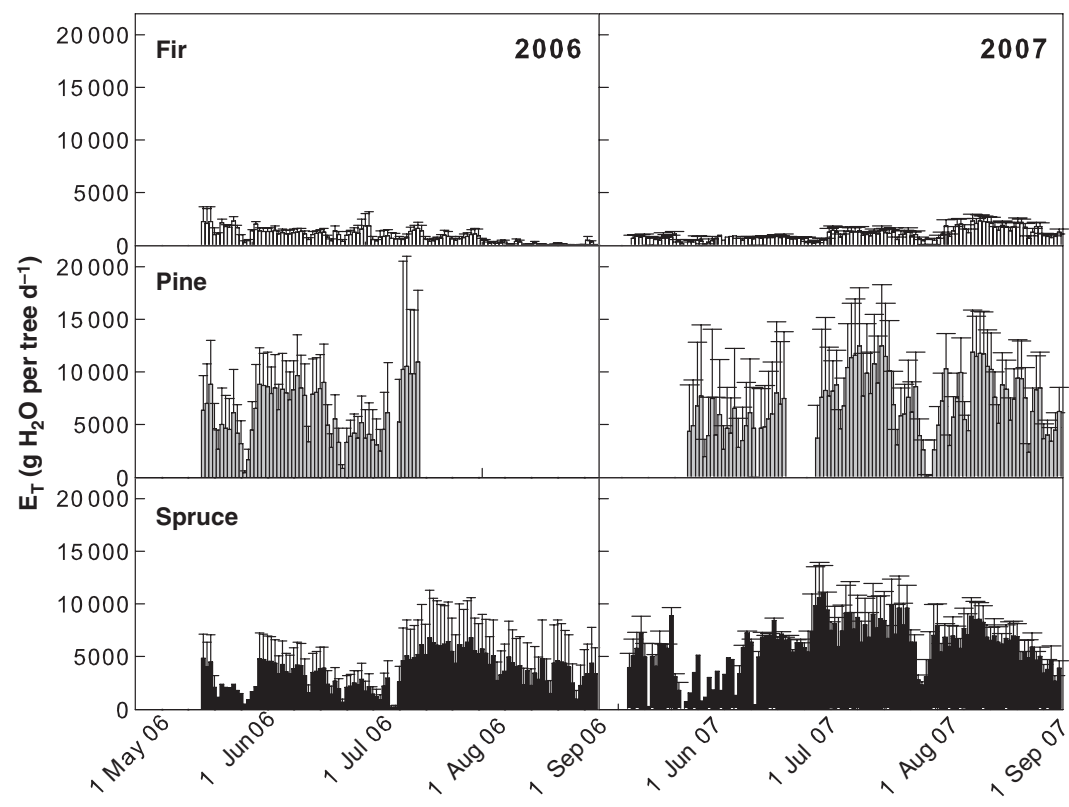

Fig. 2 Daily whole-tree transpiration rates $\left(E_{\mathrm{T}}\right)$ and transpiration per unit sapwood area $\left(E_{S A}\right)$ for 2006 and 2007 for subalpine fir (Abies lasiocarpa), lodgepole pine (Pinus contorta), and Engelmann spruce (Picea engelmannii) trees. Subalpine fir, $n=8$; lodgepole pine, $n=9$; Engelmann spruce, $n=8$. Vertical bars, + SE.

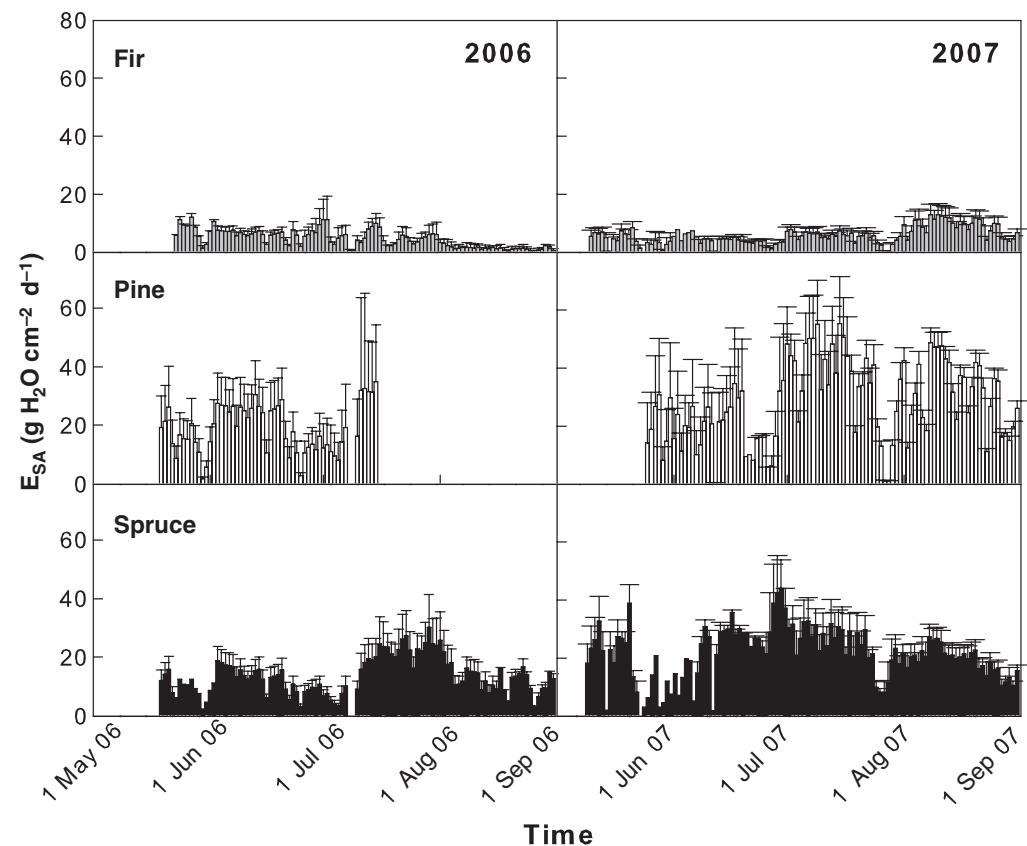

$\delta^{13} \mathrm{C}$ and $\mathrm{E}$ ranged from 0.42 to $2.78 \mathrm{~g} \mathrm{C} \mathrm{m}^{-2} \mathrm{~d}^{-1}$, with an average of value of $0.94 \mathrm{~g} \mathrm{C} \mathrm{m}^{-2} \mathrm{~d}^{-1}$ for the entire growing season. Unlike GPP derived from SIPNET, GPP derived from the scaled $\delta^{13} \mathrm{C}$ and $E$ values reached a maximum at the start of the growing season on 1 June, and decreased thereafter.

In 2007, the pattern of GPP modeled from SIPNET was similar to that of 2006, with GPP ranging from 0.53 to $2.60 \mathrm{~g} \mathrm{C} \mathrm{m}^{-2} \mathrm{~d}^{-1}$, and with a growing season average of $2.10 \mathrm{~g} \mathrm{C} \mathrm{m}^{-2} \mathrm{~d}^{-1}$. The GPP modeled from $\delta^{13} \mathrm{C}$ and $\mathrm{E}$, however, was more variable and ranged from 0.49 to $2.89 \mathrm{~g}$ $\mathrm{C} \mathrm{m} \mathrm{m}^{-2}$, with a growing season average GPP of $1.2 \mathrm{~g} \mathrm{C}$ $\mathrm{m}^{-2} \mathrm{~d}^{-1}$. The $\delta^{13} \mathrm{C}$ and $\mathrm{E}$ modeled GPP reached a maximum on 20 July.

Whole-tree carbon assimilation and GPP sensitivity analysis

We examined the sensitivity of $A_{\text {tree }}$ and GPP to changes in $\delta^{13} \mathrm{C}$ and $E$ for 2006 and 2007. The positive correlation between $\delta^{13} \mathrm{C}$ and $A_{\text {tree }}$ was significant for all three species, but the $R^{2}$-values were low (fir, $R^{2}=0.040$; pine, $R^{2}=0.018$; spruce, $R^{2}=0.056 ; P<0.001$ for all three species) (Table 4; Fig. 9). Conversely, we found a significant 

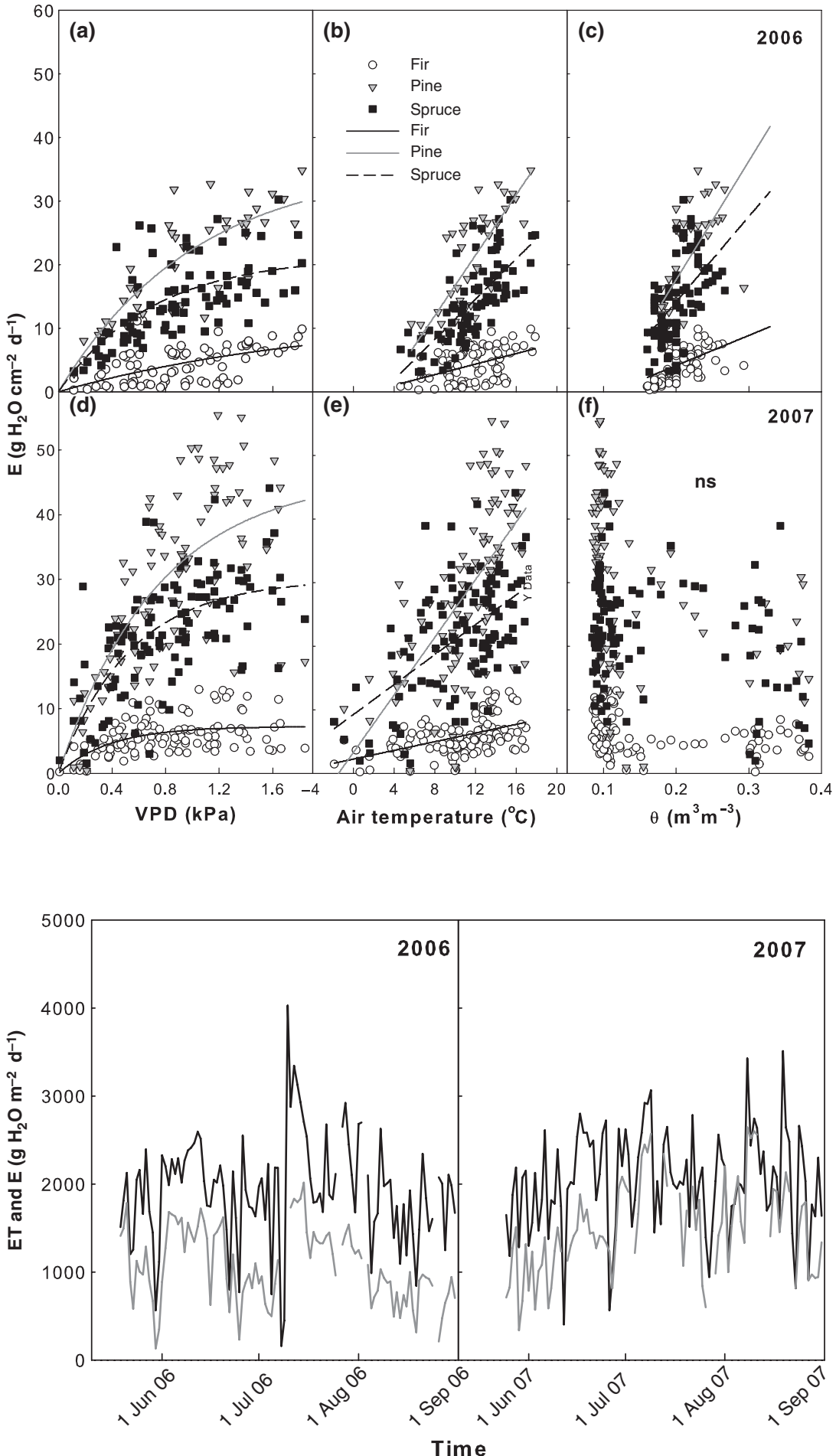

Fig. 3 (a,d) Regression relationship between transpiration per unit sapwood area $\left(E_{\mathrm{SA}}\right)$ and air temperature; $(b, e)$ relationship between $E_{S A}$ and air temperature; $(c, f)$ relationship between $E_{\mathrm{SA}}$ and vapor pressure deficit (VPD) for subalpine fir (Abies lasiocarpa), lodgepole pine (Pinus contorta), and Engelmann spruce (Picea engelmannii) trees; ns, not significant.
Fig. 4 Ecosystem evapotranspiration (ET, black line) and transpiration ( $E$, gray line) for the years 2006 and 2007. relationship between $E$ and $A_{\text {Tree}}$, and the $R^{2}$-values were high (fir, $R^{2}=0.94$; pine, $R^{2}=0.97$; spruce, $R^{2}=0.94$; $P<0.001$ for all three species) (Table 4; Fig. 9). The slope of the relationship between $\delta^{13} \mathrm{C}$ and GPP was low for all three species (fir, $R^{2}=0.0006$; pine, $R^{2}=0.02$; spruce, $R^{2}=0.06 ; P<0.05$ for all three species) (Table 4; Fig. 9).
We found a steeper slope between E and GPP (fir, $R^{2}=0.008$; pine, $R^{2}=0.93$; spruce, $R^{2}=0.03 ; P<0.001$ for all three species), especially between pine $E$ and GPP (Table 4; Fig. 9). We note that the analyses presented in Fig. 9, by nature, reflect autocorrelation between the variables plotted. However, our intent in presenting this analy- 
New

Phytologist

Fig. $5(a, b)$ Carbon isotope ratio $\left(\delta^{13} \mathrm{C}\right)$ of sun needle sugars of fir (Abies lasiocarpa; circles), pine (Pinus contorta; triangles), and spruce (Pinus contorta; squares) for 2006 and 2007; (c,d) Calculated ratio of intercellular $\mathrm{CO}_{2}$ concentration and atmospheric $\mathrm{CO}_{2}$ concentration $\left(C_{\mathrm{i}}: C_{\mathrm{a}}\right)$ of sun needles for 2006 and 2007.

sis is not to infer mechanistic connection between the variables, but rather to probe the relative sensitivities of the values modeled $\left(A_{\text {Tree }}\right.$ and GPP) to the $E$ and $\delta^{13} \mathrm{C}$ when assessed across a broad range of combinations generated through the Monte Carlo analysis.

\section{Discussion}

\section{The theoretical basis for estimating $A_{\text {Tree }}$}

Over the past two decades, the concept of plant WUE has been used to understand the coupling of the carbon and water cycles at various scales, from leaves to ecosystems. We employed this coupled relationship between leaf $\mathrm{CO}_{2}$ gain and $\mathrm{H}_{2} \mathrm{O}$ loss in order to model $A_{\text {Tree }}$. Our simple approach was driven by two implicit inferences. (1) Changes in leaf transpiration rate $(E)$ caused by changes in stomatal conductance $\left(g_{s}\right)$, should scale positively with changes in net photosynthesis rate $(A)$. (2) The ratio of $A: E$, when referenced to $v$, is reflected in the ratio $C_{\mathrm{i}}: C_{\mathrm{a}}$. Relying on these inferences we used the Farquhar et al. (1989) model to relate $\delta^{13} \mathrm{C}$ of needle sugars to $C_{\mathrm{i}}: C_{\mathrm{a}}$, calculate WUE using observations of $v$, and then isolate $A$ through multiplication by $E$ obtained from observations of xylem sap flux.

One assumption inherent in our approach is that the $\delta^{13} \mathrm{C}$ of needle sugars is coupled to dynamics in weather and climate over a 3-d period before sugar collection. Previous studies have shown that the ${ }^{13} \mathrm{C}:{ }^{12} \mathrm{C}$ ratio in needle sugars is highly correlated with weather dynamics during the few days before sugar collection (Pate \& Arthur, 1998; Keitel et al., 2003; Gessler et al., 2004; Hu et al., 2009). Furthermore, rates of sugar transport out of conifer needles can be on the scale of hours during periods of active photosynthesis (Sevanto et al., 2003). Finally, we note that $\mathrm{Hu}$ et al. (2009) did not find a mixing of 'old' and 'new' sugars during the same growing period as used in this study. Thus, all of the preceding studies suggest that turnover in needle carbohydrate pools is sufficiently fast to support our assumption of tight coupling between sugar $\delta^{13} \mathrm{C}$ and recent weather and climate.

\section{Seasonal patterns of $E$, WUE and $A_{\text {Tree }}$}

The differences in transpiration rates as well as the range of transpiration rates among the three species that we observed have been found in other studies, where subalpine fir consistently has the lowest sap flux rates per unit leaf area $\left(E_{\mathrm{LA}}\right)$ (Pataki et al., 2000) or for $E_{\mathrm{T}}$ (Kaufmann, 1985), and lodgepole pines and Engelmann spruce have relatively high $E_{\mathrm{T}}$ (Graham \& Running, 1984; Kaufmann, 1985; Pataki et al., 2000). In general, the response of $E$ in all three species to changes in soil moisture and VPD has been observed 


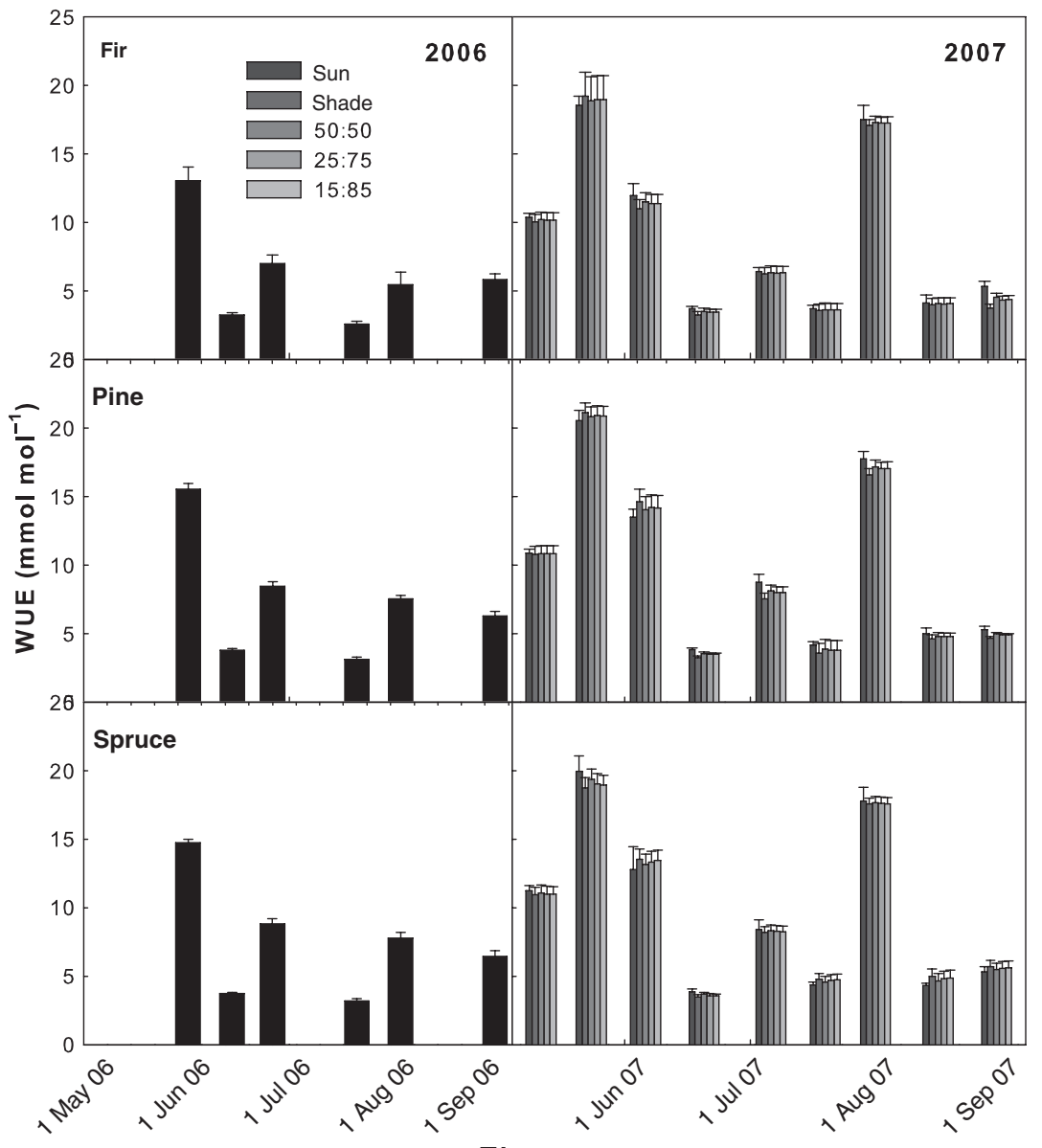

Fig. 6 Calculated photosynthetic water-use efficiency (WUE) for subalpine fir (Abies lasiocarpa), lodgepole pine (Pinus contorta), and Engelmann spruce (Picea engelmannii) for 2006 and 2007. In 2006, only sun needles were collected. In 2007, we calculated different WUE values using five different sun and shade scenarios: (1) all sun needles, (2) all shade needles, (3) $50: 50$ sun : shade, (4) $25: 75$ sun : shade, (5) $15: 85$ sun : shade. Vertical bars, + SE.
(Fetcher, 1976; Graham \& Running, 1984; Pataki et al., 2000; Moore et al., 2008), with one exception. The lack of response of $E$ to soil moisture in 2007 may be caused by the extremely 'wet' conditions during that year. With abundant soil moisture, particularly during the first half of the growing season, atmospheric drivers, such as VPD and air temperature may be more important as determinants of $E$. A comparison of $E$ and ET (Fig. 4) showed that we were able to capture similar dynamics in seasonal surface-atmosphere $\mathrm{H}_{2} \mathrm{O}$ fluxes using independent methods, and $E$ was always less than ET. We have used this comparison to derive confidence that our measures of $E$ are accurate and thus observed $E$ is a reasonable metric on which to base our estimates of $A_{\text {Tree}}$.

The seasonal patterns of WUE for all three species were largely driven by changes in air temperature and VPD. For example, in 2007, we saw a doubling of WUE among all three species on 24 May and 30 July (Fig. 6); these two periods coincided with precipitation events, which decreased both air temperature and VPD by half.

Although we generally observed the highest values of $A_{\text {Tree }}$ following snowmelt or summer rain events, and during weather with lower temperatures, we were unable to support these observations statistically. This was most likely limited by the frequency at which we could determine sugar $\delta^{13} \mathrm{C}$ values. However, as WUE is sensitive to changes in VPD (Eqn 5) and $E$ responds to both changes in VPD and soil moisture (Fetcher, 1976; Graham \& Running, 1984; Pataki et al., 2000; Moore et al., 2008), we expect that the highest $A_{\text {Tree }}$ values should occur following snowmelt or rain events because low VPD leads to high WUE, high soil moisture leads to high $E$ and both high WUE and $E$ rates would result in high rates of $A_{\text {Tree }}$.

\section{Comparison of different models for estimating GPP}

Values of GPP derived from $\delta^{13} \mathrm{C}$ and $E$ were consistently lower than GPP modeled by SIPNET. The SIPNET GPP is estimated after assimilating NEP from tower flux observations and so any biases in the tower fluxes will propagate to the SIPNET predictions. We know from previous studies that the estimates of net $\mathrm{CO}_{2}$ exchange, principally during nighttime respiration, derived from the tower flux estimates are likely to be underestimated owing to inadequate consideration of advective $\mathrm{CO}_{2}$ fluxes at the Niwot Ridge site (Yi et al., 2008). If NEP observations are biased toward slightly 
New

Phytologist

Fig. 7 Calculated whole-tree carbon assimilation rate $\left(A_{\text {Tree }}\right)$ for subalpine fir (Abies lasiocarpa), lodgepole pine (Pinus contorta) and Engelmann spruce (Picea engelmannii) for 2006 and 2007. In 2006, only sun needles were collected. In 2007, $A_{\text {Tree }}$ values were calculated using five different sun and shade scenarios: (1) all sun needles, (2) all shade needles, (3) $50: 50$ sun : shade, (4) $25: 75$ sun : shade, and (5) $15: 85$ sun : shade. Vertical bars, +SE.

Fig. 8 Left $y$-axis: a comparison of gross primary productivity (GPP) modeled using $\delta^{13} \mathrm{C}$ and transpiration (E) (open circles), and GPP modeled from the simplified photosynthesis and evapotranspiration model (SIPNET; closed circles) for 2006 and 2007. Error bars represent 95\% confidence intervals generated by Monte Carlo analysis. Dashed horizontal lines, mean annual GPP modeled using $\delta^{13} \mathrm{C}$ and $E$; solid horizontal lines, mean annual GPP modeled using SIPNET. Right $y$ axis: daily precipitation for 2006 and 2007.

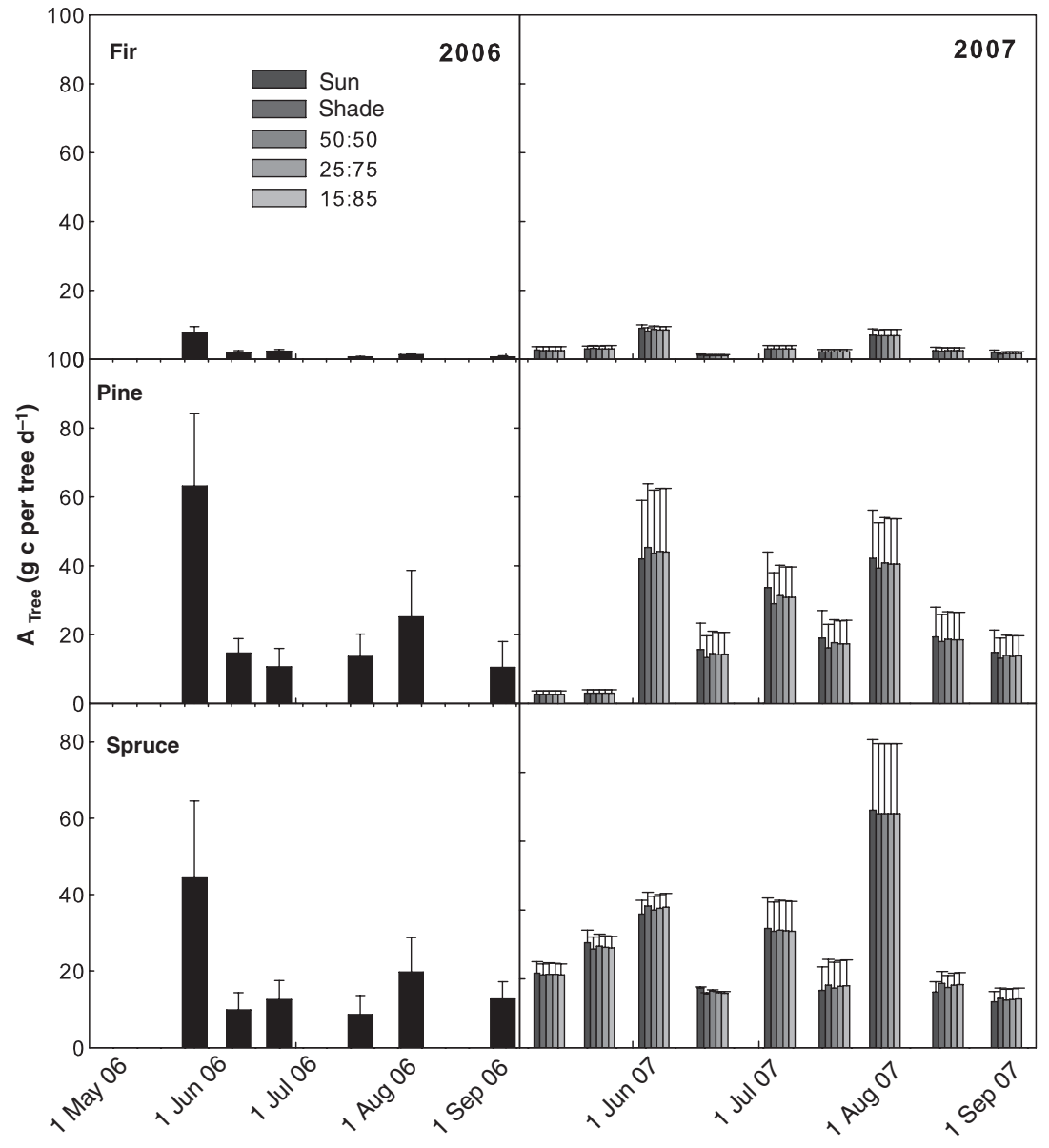

Time

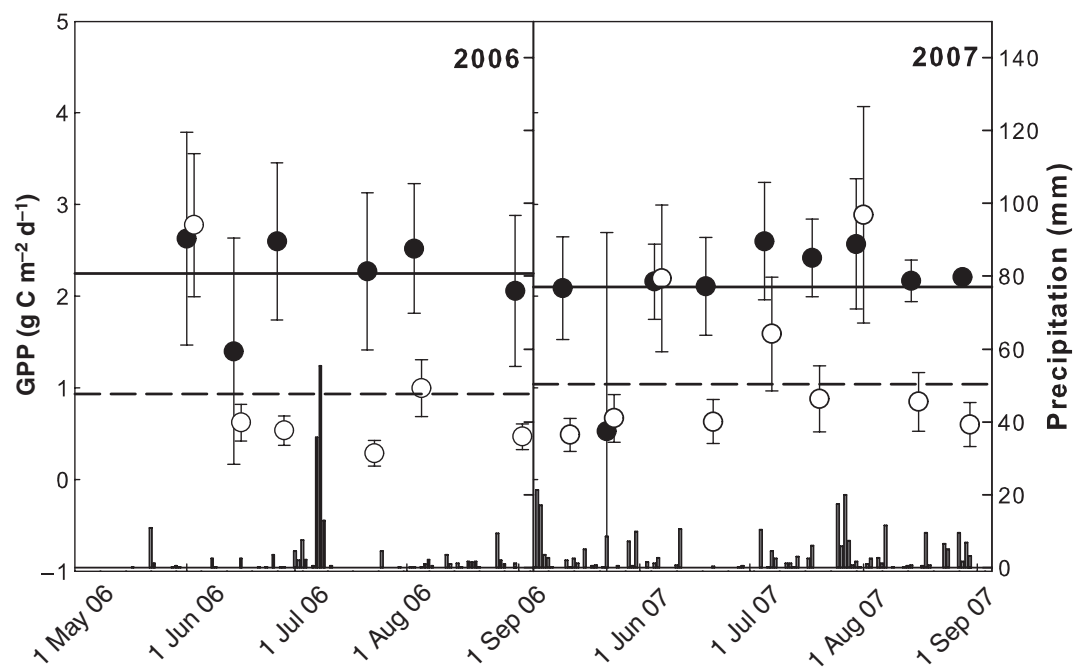

Time higher $\mathrm{CO}_{2}$ uptake rates, owing to underestimation of night-time respiration rates, then they will yield GPP estimates that are slightly too high when assimilated into SIP-
NET. Despite the differences in predicted GPP between these two models, both models converged on similar GPP values when both models calculated periods of high GPP 
Table 4 Statistical results from the sensitivity analysis

\begin{tabular}{lll}
\hline & $\delta^{13} \mathrm{C}$ and $A_{\text {Tree }}$ & $E$ and $A_{\text {Tree }}$ \\
\hline Subalpine fir & $R^{2}=0.040, P<0.001$ & $R^{2}=0.94, P<0.001$ \\
& $A_{\text {Tree }}=0.34 \delta^{13} \mathrm{C}+11.81$ & $A_{\text {Tree }}=0.0035 E+0.0018$ \\
Lodgepole pine & $R^{2}=0.018, P<0.001$ & $R^{2}=0.97, P<0.001$ \\
& $A_{\text {Tree }}=1.95 \delta^{13} \mathrm{C}+67.10$ & $A_{\text {Tree }}=0.0041 E-0.0021$ \\
Engelmann spruce & $R^{2}=0.056, P<0.001$ & $R^{2}=0.94, P<0.001$ \\
& $A_{\text {Tree }}=2.64 \delta^{13} \mathrm{C}+90.76$ & $A_{\text {Tree }}=0.0040 E-0.030$ \\
\hline & $\delta^{13} \mathrm{C}$ and GPP & $E$ and GPP \\
\cline { 2 - 3 } & $R^{2}=0.0006, P=0.02$ & $R^{2}=0.008, P<0.001$ \\
Subalpine fir & $\mathrm{GPP}=0.01 \delta^{13} \mathrm{C}+1.10$ & $\mathrm{GPP}=0.72 E+0009$ \\
Lodgepole pine & $R^{2}=0.02, P<0.001$ & pine: $R^{2}=0.93, P<0.001$ \\
Engelmann spruce & $\mathrm{GPP}=0.07 \delta^{13} \mathrm{C}+2.75$ & $\mathrm{GPP}=0.28 E+0.0001$ \\
& $R^{2}=0.06 P<0.001$ & $R^{2}=0.03 P<0.001$ \\
$\mathrm{GPP}=0.04 \delta^{13} \mathrm{C}+1.82$ & $\mathrm{GPP}=0.55 E+0.0004$ \\
\hline
\end{tabular}

$A_{\text {Tree, }}$ whole tree $\mathrm{CO}_{2}$ assimilation rate; $E$, tree transpiration rate; GPP, gross primary productivity.

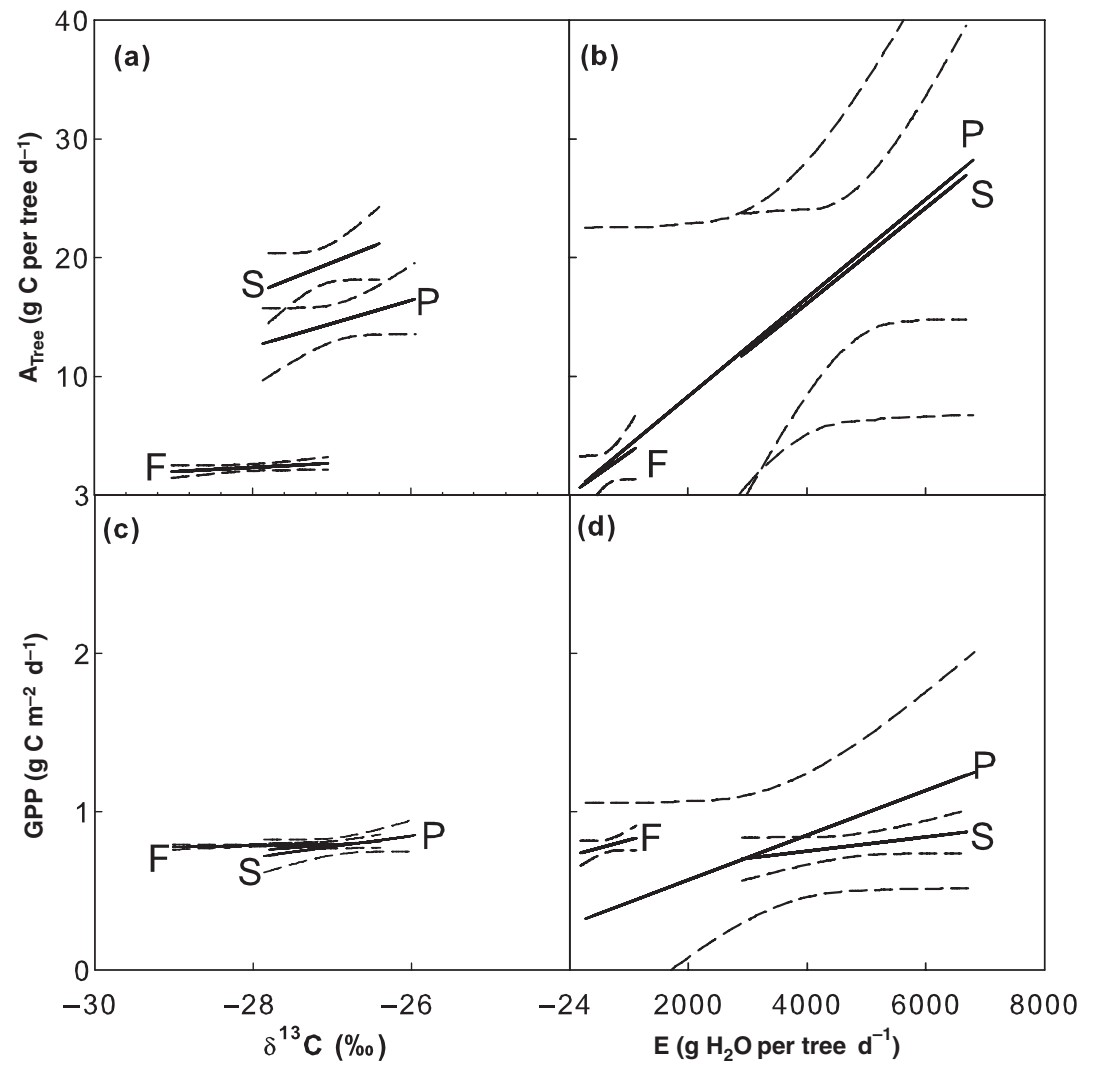

Fig. 9 Whole-tree $\mathrm{CO}_{2}$ assimilation rate $\left(A_{\text {Tree }}\right)$ and gross primary productivity (GPP) sensitivity analysis. F, subalpine fir (Abies lasiocarpa); P, lodgepole pine (Pinus contorta); $S$, Engelmann spruce (Picea engelmannii). The bold black lines are the regression relationships and the gray thin lines are the $95 \%$ confidence intervals for the data. (a) Relationship between $\delta^{13} \mathrm{C}$ and $\mathrm{A}_{\text {Tree }}$ for all three species (fir, $R^{2}=0.040, P<0.001$; pine, $R^{2}=0.018, P<0.001 ;$ spruce, $R^{2}=0.056$, $P<0.001$ ). (b) Relationship between transpiration (E) and $A_{\text {Tree }}$ (fir, $R^{2}=0.94$, $P<0.001$; pine, $R^{2}=0.97, P<0.001$; spruce, $R^{2}=0.94, P<0.001$ ). (c) Relationship between $\delta^{13} \mathrm{C}$ and GPP (fir, $R^{2}=0.0006, P=0.02$; pine, $R^{2}=0.02$, $P<0.0001$; spruce, $R^{2}=0.06, P<0.001$ ). (d) Relationship between $E$ and GPP (fir, $R^{2}=0.008, P<0.001$; pine, $R^{2}=0.93$, $P<0.001$; spruce, $R^{2}=0.03 P<0.0001$ ).
(Fig. 8). Periods of high GPP from $A_{\text {Tree }}$ would occur when sap flux rates are highest, and high GPP from SIPNET would occur when advective $\mathrm{CO}_{2}$ fluxes are lowest; thus, the errors that might be causing the gap between the two estimates may be lowest when fluxes are highest. Furthermore, the few dates available to compare both modeling approaches may also have contributed to the different estimates of GPP. With only six dates in 2006 and nine dates in 2007 for comparison, we were unable to capture more frequent changes in $\delta^{13} \mathrm{C}$ (and subsequent changes in WUE and $\left.A_{\text {Tree }}\right)$.

\section{Sensitivity analysis}

Through our sensitivity analysis, we found that the dynamics in the estimates of $A_{\text {Tree }}$ were driven principally 
by dynamics in $E$. Covariance between $E$ and $A_{\text {Tree }}$ is forced on theoretical grounds by the fact that $\mathrm{CO}_{2}$ and $\mathrm{H}_{2} \mathrm{O}$ are exchanged through the same stomatal pores. In our model, the proportioning coefficient between $E$ and $A$ is $\delta^{13} \mathrm{C}$, which is ultimately dependent on the scaling between $A$ and $g_{s}$. Once again, because of the codependence of $A$ and $E$ on $g_{s}$, we are able to infer mechanistic connections between $\delta^{13} \mathrm{C}$ and $E$, as long as we also accounted for the influence of leaf-to-air vapor pressure difference, $v$. Variation in $\delta^{13} \mathrm{C}$ among species and across seasonal climate gradients is small, compared with variation in $E$, partly because $\delta^{13} \mathrm{C}$ is mathematically constrained as the ratio of two covarying fluxes, and partly because stomata function in a way that optimizes $A: g_{\text {s }}$ toward conserved values across $\mathrm{C}_{3}$ species and in response to environmental gradients (Wong et al., 1979; Drake et al., 1997; Ellsworth, 1999). Other researchers have also utilized to their advantage the fact that $A: E$, and therefore $C_{\mathrm{i}}: C_{\mathrm{a}}$ tends to be conserved across environments, and thus most change in $A$ can be predicted through changes in $g_{s}$ (Norman, 1982). At one extreme, with the assumption that changes in $C_{\mathrm{i}} ; C_{\mathrm{a}}$ are negligible, compared with changes in $g_{s}, A: E$ can potentially be treated as a constant. Taking changes in $C_{\mathrm{i}}: C_{\mathrm{a}}$ as small, but not negligible, the case still remains that small changes in $A: E$ translate into concomitantly small changes in $A_{\text {Tree }}$, when multiplied by constant $E$; however, small changes in $E$ can translate into large changes in $A_{\text {Tree }}$ when multiplied by constant $A: E$. Following these inferences, we interpret the relatively large interspecific differences in $A_{\text {Tree }}$ (Fig. 7) to principally reflect differences in $E$ (and therefore differences in $g_{s}$ ) (Schäfer et al., 2002; Kim et al., 2008).

In order to further study the sensitivity of GPP to changes in $E$ vs $\delta^{13} \mathrm{C}$, we conducted a formal sensitivity analysis (Fig. 9). Using this Monte Carlo approach, we were able to deploy many more combinations of $E$ and $\delta^{13} \mathrm{C}$ than those obtained from our limited number of sampling dates, and thus assess sensitivity across the full range of possible values. Similar to our sensitivity analysis of $A_{\text {Tree }}$, we also found that GPP was also more sensitive to $E$ than to $\delta^{13} \mathrm{C}$; however, in this case, we found that the sensitivity of GPP to $E$ was largely driven by one species, pine (Fig. 9). The large range in $E$ in pine trees, combined with the relatively high sensitivity of GPP to $E$ in general, means that dynamics in GPP in this forest stand are likely to be driven most by dynamics in pine $A_{\text {Tree }}$. It should be noted that the analysis shown in Fig. 9 included consideration of actual species distributions in the forest community surrounding the Niwot Ridge flux tower. Thus, the higher GPP predicted for pine also reflects the relatively high fractional representation in the community.

The $A_{\text {Tree }}$ value was not significantly sensitive to the effect of sun vs shade needle partitioning and, once again, the relatively high sensitivity of the model to $E$, and low sensitivity to $\delta^{13} \mathrm{C}$ explains this result. One source of potential error that may be significant in the model is the uncertainty in estimating whole-tree $E$. Error in whole-tree $E$ can occur in measurements of sap flow velocity $\left(V_{\mathrm{h}}\right)$, estimation of wood properties, radial patterns of sapwood (Phillips et al., 1996; Cermak \& Nadezhdina, 1998) and water storage in the stem (Ewers \& Oren, 2000). We accounted for errors in $E$ using the Monte Carlo approach, where we generated 99\% intervals for our modeled GPP values. No values fell outside our 99\% confidence intervals, suggesting that most errors of $E$ are accounted for in our modeled GPP rates.

Through this study, we have presented a method for combining measurements of needle sugar $\delta^{13} \mathrm{C}$ and wholetree $E$ to calculate whole-tree carbon assimilation on the time-scale of days. Our approach used calculated whole tree WUE using the $\delta^{13} \mathrm{C}$ of needles sugars, which should reflect influences on carbon assimilation at the shorter time-scale. We scaled our values of $A_{\text {Tree }}$ to GPP, which we then compared with another independent estimate of GPP using SIPNET. There were differences in estimates produced by these two approaches, but given the fact that one set is scaled to tree measurements of sap flux and one is scaled to eddy flux measurements of ecosystem $\mathrm{CO}_{2}$ and $\mathrm{H}_{2} \mathrm{O}$ fluxes, we are generally optimistic that the two approaches are based on reasonably sound foundations. More frequent sampling of needle sugar $\delta^{13} \mathrm{C}$ and more frequent calculations of WUE and $A_{\text {Tree }}$ are needed to close the gap between these approaches and accurately capture the seasonal trends. Nonetheless, our study provides the framework for modeling whole-tree assimilation using nondestructive techniques than can be measured and applied at short time-scales.

\section{Acknowledgements}

We thank J. Monical, S. Love-Stowell, D. Koffler and S. Burgess for data collection. We also thank Ram Oren, Lawren Sack and one anonymous reviewer for helpful comments on the original manuscript. This research was supported by the Western Section of the National Institute for Climate Change Research (NICCR) (Award MPC35TX-A2) and two grants from the US National Science Foundation (Biocomplexity Program; Grant EAR 0321918 and DDIG; Grant DEB 0709252).

\section{References}

Aber JD, Federer CA. 1992. A generalized, lumped-parameter model of photosynthesis, evapotranspiration and net primary production in temperate and boreal forest ecosystems. Oecologia 92: 463-474.

Aber JD, Ollinger SV, Federer CA, Reich PB, Goulden ML, Kicklighter DW, Melillo JM, Lathrop RG. 1995. Predicting the effects of climate change on water yield and forest production in the northeastern United States. Climate Research 5: 207-222. 
Aber JD, Reich PB, Goulden ML. 1996. Extrapolating leaf $\mathrm{CO}_{2}$ exchange to the canopy: a generalized model of forest photosynthesis compared with measurements by eddy correlation. Oecologia 106: 257-265.

Angert A, Biraud S, Bonfils C, Henning CC, Buermann W, Pinzon J, Tucker CJ, Fung I. 2005. Drier summers cancel out the $\mathrm{CO}_{2}$ uptake enhancement induced by warmer springs. Proceedings of the National Academy of Sciences, USA 102: 10823-10827.

Baldocchi DD. 2003. Assessing the eddy covariance technique for evaluating carbon dioxide exchange rates of ecosystems: past, present and future. Global Change Biology 9: 479-492.

Baldocchi DD, Wilson KB. 2001. Modeling $\mathrm{CO}_{2}$ and water vapor exchange of a temperate broadleaved forest across hourly to decadal time scales. Ecological Modelling 142: 155-184.

Baldocchi DD, Hicks BB, Meyers TP. 1988. Measuring biosphere-atmosphere exchanges of biologically related gases with micrometeorological methods. Ecology 69: 1331-1340.

Barford CC, Wofsy SC, Goulden ML, Munger JW, Pyle EH, Urbanski SP, Hutyra L, Saleska SR, Fitzjarrald D, Moore K. 2001. Factors controlling long- and short-term sequestration of atmospheric $\mathrm{CO}_{2}$ in a mid-latitude forest. Science 294: 1688-1691.

Bowling DR, Burns SP, Conway TJ, Monson RK, White JWC. 2005. Extensive observations of $\mathrm{CO}_{2}$ carbon isotope content in and above a high-elevation subalpine forest. Global Biogeochemical Cycles 19: GB 3023.

Braswell BH, Sacks WJ, Linder E, Schimel DS. 2005. Estimating diurnal to annual ecosystem parameters by synthesis of a carbon flux model with eddy covariance net ecosystem exchange observations. Global Change Biology 11: 335-355.

Burgess SSO, Adams M, Turner NC, Beverly CR, Ong CK, Khan AAH, Bleby TM. 2001. An improved heat pulse method to measure low and reverse rates of sap flow in woody plants. Tree Physiology 21: 589-598.

Campbell GS. 1977. An introduction to environmental biophysics. New York, NY, USA: Springer-Verlag.

Canadell JG, Mooney HA, Baldocchi DD, Berry JA, Ehleringer JR, Field CB, Gower ST, Hollinger DY, Hunt JE, Jackson RB et al. 2000. Carbon metabolism of the terrestrial biosphere: a multi-technique approach for improved understanding. Ecosystems 3: 115-130.

Cermak J, Nadezhdina N. 1998. Sapwood as the scaling parameter defining according to xylem water content or radial pattern of sap flow? $A n-$ nales Des Sciences Forestieres 55: 509-521.

Clark DA, Brown S, Kicklighter DW, Chambers JQ, Thomlinson JR, Ni J. 2001. Measuring net primary production in forests: concepts and field methods. Ecological Applications 11: 356-370.

Clark KL, Skowronski N, Hom J 2009. Invasive insects impact forest carbon dynamics. Global Change Biology. doi: 10.1111/j.13652486.2009.01983x

Denmead OT, Dunin FX, Wong SC, Greenwood EAN. 1993. Measuring water-use efficiency of eucalypt trees with chambers and micrometeorological techniques. Journal of Hydrology 150: 649-664.

Drake BG, Gonzalez-Meler MA, Long SP. 1997. More efficient plants: a consequence of rising atmospheric $\mathrm{CO}_{2}$ ? Annual Review of Plant Physiology and Plant Molecular Biology 48: 609-639.

Ellsworth DS. 1999. $\mathrm{CO}_{2}$ enrichment in a maturing pine forest: are $\mathrm{CO}_{2}$ exchange and water status in the canopy affected? Plant, Cell \& Environment 22: 461-472.

Ewers BE, Oren R. 2000. Analyses of assumptions and errors in the calculation of stomatal conductance from sap flux measurements. Tree Physiology 20: 579-589.

Farquhar GD, Caemmerer SV, Berry JA. 1980. A biochemical-model of photosynthetic $\mathrm{CO}_{2}$ assimilation in leaves of C-3species. Planta 149: 78-90.

Farquhar GD, Oleary MH, Berry JA. 1982. On the relationship between carbon isotope discrimination and the inter-cellular carbon-dioxide concentration in leaves. Australian Journal of Plant Physiology 9: 121-137.
Farquhar GD, Ehleringer JR, Hubick KT. 1989. Carbon isotope discrimination and photosynthesis. Annual Review of Plant Physiology and Plant Molecular Biology 40: 503-537.

Fetcher N. 1976. Patterns of leaf resistance to lodgepole pine transpiration in Wyoming. Ecology 57: 339-345.

Field C, Berry JA, Mooney HA. 1982. A portable system for measuring carbon-dioxide and water-vapor exchange of leaves. Plant, Cell \& Environment 5: 179-186.

Gessler A, Rennenberg H, Keitel C. 2004. Stable isotope composition of organic compounds transported in the phloem of European beech evaluation of different methods of phloem sap collection and assessment of gradients in carbon isotope composition during leaf-to-stem transport. Plant Biology 6: 721-729.

Goetz SJ, Bunn AG, Fiske GJ, Houghton RA. 2005. Satellite-observed photosynthetic trends across boreal North America associated with climate and fire disturbance. Proceedings of the National Academy of Sciences, USA 102: 13521-13525.

Graham JS, Running SW. 1984. Relative control of air-temperature and water status on seasonal transpiration of Pinus contorta. Canadian Journal of Forest Research - Revue Canadienne De Recherche Forestiere 14: 833-838.

Hollinger DY, Richardson AD. 2005. Uncertainty in eddy covariance measurements and its application to physiological models. Tree Physiology 25: 873-885.

Hu J, Moore DJP, Monson RK. 2009. Weather and climate controls over the seasonal carbon isotope dynamics of sugars from subalpine forest trees. Plant, Cell \& Environment doi: 0.111/j.1365-3040.2009. 02059.x.

Huxman TE, Turnipseed AA, Sparks JP, Harley PC, Monson RK. 2003. Temperature as a control over ecosystem $\mathrm{CO}_{2}$ fluxes in a high-elevation, subalpine forest. Oecologia 134: 537-546.

Kaufmann MR. 1985. Annual transpiration in sub-alpine forests - large differences among 4 tree species. Forest Ecology and Management 13: 235-246.

Keitel C, Adams MA, Holst T, Matzarakis A, Mayer H, Rennenberg H, Gessler A. 2003. Carbon and oxygen isotope composition of organic compounds in the phloem sap provides a short-term measure for stomatal conductance of European beech (Fagus sylvatica L.). Plant, Cell \& Environment 26: 1157-1168.

Kim HS, Oren R, Hinckley TM. 2008. Actual and potential transpiration and carbon assimilation in an irrigated poplar plantation. Tree Physiology 28: 559-577.

Lloyd J, Farquhar GD. 1994. C-13 discrimination during $\mathrm{CO}_{2}$ assimilation by the terrestrial biosphere. Oecologia 99: 201-215.

Mark WR, Crews DL. 1973. Heat-pulse velocity and bordered pit condition in living Engelmann spruce and lodgepole pine trees. Forest Science 19: 291-296.

Marshall DC. 1958. Measurement of sap flow in conifers by heat transport. Plant Physiology 33: 385-396.

McGee GG, Leopold DJ, Nyland RD. 1999. Structural characteristics of old-growth, maturing, and partially cut northern hardwood forests. Ecological Applications 9: 1316-1329.

Monson RK, Turnipseed AA, Sparks JP, Harley PC, Scott-Denton LE, Sparks K, Huxman TE. 2002. Carbon sequestration in a high-elevation, subalpine forest. Global Change Biology 8: 459-478.

Monson RK, Sparks JP, Rosenstiel TN, Scott-Denton LE, Huxman TE, Harley PC, Turnipseed AA, Burns SP, Backlund B, Hu J. 2005. Climatic influences on net ecosystem $\mathrm{CO}_{2}$ exchange during the transition from wintertime carbon source to springtime carbon sink in a high-elevation, subalpine forest. Oecologia 146: 130-147.

Monson RK, Prater MR, Hu J, Burns SP, Sparks JP, Sparks KL, Scott-Denton LE. 2009. Tree species effects on ecosystem water-use efficiency in a high-elevation, subalpine forest. Oecologia. doi: $10.1007 / s 00442-009-1465-z$ 
Moore DJP, Hu J, Sacks WJ, Schimel DS, Monson RK. 2008. Estimating transpiration and the sensitivity of carbon uptake to water availability in a subalpine forest using a simple ecosystem process model informed by measured net $\mathrm{CO}_{2}$ and $\mathrm{H}_{2} \mathrm{O}$ fluxes. Agricultural and Forest Meteorology 148: $1467-1477$.

Myneni RB, Keeling CD, Tucker CJ, Asrar G, Nemani RR. 1997. Increased plant growth in the northern high latitudes from 1981 to 1991. Nature 386: 698-702.

Norman JM. 1982. Simulation of microclimates. In: Hatfield JL, Thomason IJ, eds. Biometeorology in integrated pest management. New York, NY, USA: Academic Press, 65-69.

Pataki DE, Oren R, Smith WK. 2000. Sap flux of co-occurring species in a western subalpine forest during seasonal soil drought. Ecology 81: 2557-2566.

Pate J, Arthur D. 1998. Delta C-13 analysis of phloem sap carbon: novel means of evaluating seasonal water stress and interpreting carbon isotope signatures of foliage and trunk wood of Eucalyptus globulus. Oecologia 117: 301-311.

Phillips N, Oren R, Zimmermann R. 1996. Radial patterns of xylem sap flow in non-, diffuse- and ring-porous tree species. Plant, Cell \& Environment 19: 983-990.

Ricciuto DM, Butler MP, Davis KJ, Cook BD, Bakwin PS, Andrews A Teclaw RM. 2008. Causes of interannual variability in ecosystematmosphere $\mathrm{CO}_{2}$ exchange in a northern Wisconsin forest using a Bayesian model calibration. Agricultural and Forest Meteorology 148: 309-327.

Running SW, Baldocchi DD, Turner DP, Gower ST, Bakwin PS, Hibbard KA. 1999. A global terrestrial monitoring network integrating tower fluxes, flask sampling, ecosystem modeling and EOS satellite data. Remote Sensing of Environment 70: 108-127.

Sacks WJ, Schimel DS, Monson RK, Braswell BH. 2006. Model-data synthesis of diurnal and seasonal $\mathrm{CO}_{2}$ fluxes at Niwot Ridge, Colorado. Global Change Biology 12: 240-259.

Sacks WJ, Schimel DS, Monson RK. 2007. Coupling between carbon cycling and climate in a high-elevation, subalpine forest: a model-data fusion analysis. Oecologia 151: 54-68.

Schäfer KVR, Oren R, Lai CT, Katul GG. 2002. Hydrologic balance in an intact temperate forest ecosystem under ambient and elevated atmospheric $\mathrm{CO}_{2}$ concentration. Global Change Biology 8: 895-911.

Schäfer KVR, Oren R, Ellsworth DS, Lai CT, Herrick JD, Finzi AC, Richter DD, Katul GG. 2003. Exposure to an enriched $\mathrm{CO}_{2}$ atmo- sphere alters carbon assimilation and allocation in a pine forest ecosystem. Global Change Biology 9: 1378-1400.

Schäfer KVR, Clark KL, Skowronski N, Hamerlyncks EP. 2009. Impact of insect defoliation on forest carbon balance as assessed with a canopy assimilation model. Global Change Biology. doi: 10.1111/j.13652486.2009.02037.x

Schimel D, Kittel T, Running S, Monson R, Turnipseed A, Anderson D. 2002. Carbon sequestration studied in western U.S. Mountains. Eos, Transactions, American Geophysical Union 83: 445.

Seibt U, Rajabi A, Griffiths H, Berry JA. 2008. Carbon isotopes and water use efficiency: sense and sensitivity. Oecologia 155: 441-454.

Sevanto S, Vesala T, Peramaki M, Nikinmaa E. 2003. Sugar transport together with environmental conditions controls time lags between xylem and stem diameter changes. Plant, Cell \& Environment 26: $1257-$ 1265.

Wingate L, Seibt U, Moncrieff JB, Jarvis PG, Lloyd J. 2007. Variations in C-13 discrimination during $\mathrm{CO}_{2}$ exchange by Picea sitchensis branches in the field. Plant, Cell \& Environment 30: 600-616.

Wong SC, Cowan IR, Farquhar GD. 1979. Stomatal conductance correlates with photosynthetic capacity. Nature 282: 424-426.

Yi CX, Anderson DE, Turnipseed AA, Burns SP, Sparks JP, Stannard DI, Monson RK. 2008. The contribution of advective fluxes to net ecosystem exchange in a high-elevation, subalpine forest. Ecological Applications 18: $1379-1390$

\section{Supporting Information}

Additional supporting information may be found in the online version of this article.

Methods S1 Soluble sugar extraction method.

Methods S2 Water-use efficiency.

Please note: Wiley-Blackwell are not responsible for the content or functionality of any supporting information supplied by the authors. Any queries (other than missing material) should be directed to the New Phytologist Central Office. 